\title{
Analysis of Palm-Oil-Based Biodiesel in Indonesia using Technological Innovation System Approach
}

\author{
Dintani Naimah ${ }^{1,{ }^{*}}$ and Maria Morgunova ${ }^{2}$ \\ ${ }^{1}$ Sustainable Energy Engineering, KTH Kungliga Tekniska Hogskolan, Sweden \\ ${ }^{2}$ Industrial Economics and Management, KTH Kungliga Tekniska Hogskolan, Sweden
}

\begin{abstract}
Biodiesel blending mandate has been established in Indonesia since 2006. After 11 years of implementation, the level of biodiesel penetration on the market is still lower than the target. Technological Innovation System (TIS) approach allows to map factors that influence, either hinder or boost, the diffusion of biodiesel technology. The challenges that should be addressed are tax regulation; price fluctuation due to Crude Palm Oil (CPO) and fossil fuel price; lack of awareness from the society; inconsistency of policy; vulnerable financial funding from palm oil tax levy; lack of sustainability indicators for palm oil; and policy objection regarding palm oil tax levy. We suggest that an agreement, which contains commitment and willingness from all actors involved, should be created to reduce uncertainty towards implementation of biodiesel. Government should not only put incentive to the emerging technology but also reduce competition within the incumbent energy system to increase and stabilize biodiesel demand. Another way to increase biodiesel demand would be to raise awareness about negative consequences of increasing fossil fuel consumption and the benefits of biodiesel for the society.
\end{abstract}

\section{Background}

Indonesia is the biggest archipelago country with emerging economy. The country is rich with numerous energy sources, both with renewables and fossils. However, Indonesia still depends on fossil-based energy, as shown in Figure 1.

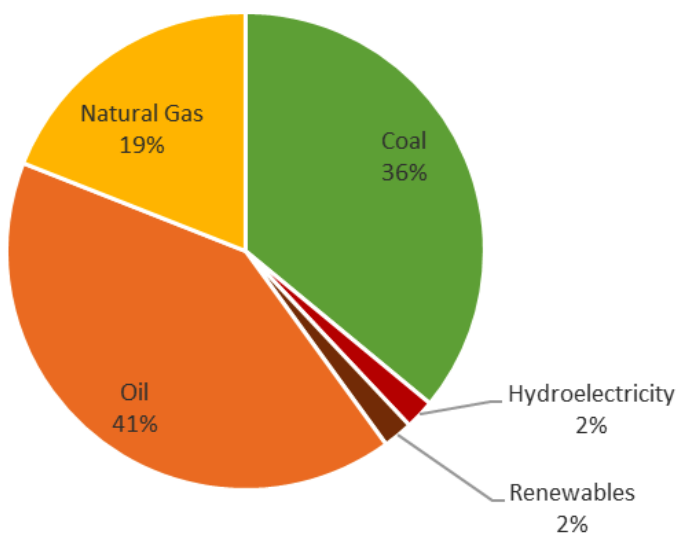

Fig. 1. Indonesia total energy consumption in 2016 [1]

In 2016, oil consumption has reached $41 \%$ of total energy consumption in Indonesia. The oil share is slowly but steady increasing [2]. $27 \%$ of this share is consumed by transport sector.

Dependence on oil is increasing since the number of road vehicles is growing [3]. During the period 2011-
2015 the total number of road vehicles, i.e. passenger cars, bus, trucks, and motorcycles, has increased from 85.6 million to 121.4 million units $(9.13 \%$ p.a.).

In order to reduce the dependence on oil fuel, the Government of Indonesia (GoI) enforced a blending mandate for biodiesel in 2006. A target was to increase share of biofuel to $5 \%$ of a total primary energy supply (TPES) by 2025 . The blending mandate for biodiesel kept evolving over the years, where according to the latest version dated December 2015 (enforced through the Ministry of Energy and Mineral Resources, MEMR) the fossil-based diesel in transport sector should contain $20 \%$ of biodiesel by 2016 . The blending composition between diesel and biodiesel should be increased to $30 \%$ by 2020 .

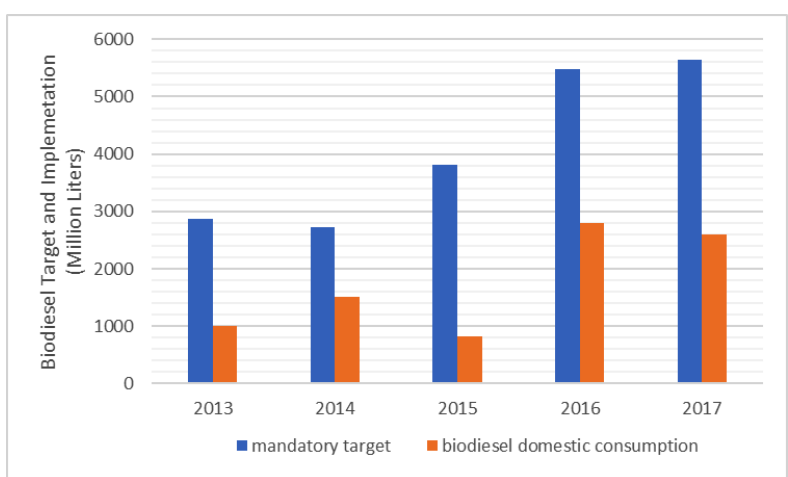

Fig. 2. Biodiesel target and actual implementation [4] 
Even though the level of blended biodiesel has significantly increased in the past few years, the actual blending and the produced volumes of biodiesel is still lower than it is prescribed by the mandate [4]. This study aims to determine the factors that hamper and foster diffusion of biodiesel in Indonesian market.

Factors that hinder biodiesel development could be grouped into technical, market, social, and policy factors [5]. Some of those challenges should have already been overcome, due to implementation of advanced technology in biorefineries, standard quality regulation for biodiesel and many other now existing supporting regulations. The attempts to improve the biodiesel implementation also included in-depth analysis regarding network of actors in biodiesel business. For example, Purwanto et al [6] proposed a long-term strategy for sustainable biodiesel development in Indonesia based on the SWOT-analysis and Multi Actor Approach. According to the study, GoI has to secure palm oil for biodiesel production, enhance sustainability of palm oil plantation, and improve collaboration with other stakeholders. Purwanto et al [4] developed the recommendation by using Duri, Riau Province, as case study.

Nevertheless, the key challenges are still present. First, uncertainty of biodiesel implementation, including inconsistency of pricing mechanism and its policy. Second, lack of awareness in society regarding the biodiesel and its advantages. Finally, biodiesel market in Indonesia is still on its early stage.

With aim to study the bigger system perspective and to discover the future development possibilities we suggest to examine the deployment of biodiesel in Indonesia using Technological Innovation System (TIS) approach. Thus, the biodiesel industry can be studied as a system with many actors connected through networks. Each actor can be evaluated whether it fulfils its functions on a way to successful biodiesel penetration. This paper results in policy recommendations for successful deployment of biodiesel in Indonesia.

\section{Method}

TIS approach allows to analyse an emerging technology as a system, in which each actor does their key functions and is connected to other stakeholders. TIS is an effective approach to map dynamics of technological innovation process.

According to TIS, the innovation system is divided into three structural components, i.e. actors, networks and institutions. The actors are involved within the whole value chain, which in this case is biodiesel. Actors are linked through the network, which allows them to exchange knowledge in order to deploy the technology. The final component, institutions, is legal framework where the emerging technology gains ground. Actors within TIS are not only competing on the market, but also influence the institutional alignment. Changing the institutional context could either foster or limit the diffusion of technology. All TIS components should be evaluated to determine its strengths and weaknesses, so that guiding policy to succeed the diffusion of technology could be developed.

Bergek et al. (2008) and Hekkert et al. (2007) proposed evaluation of functions of innovation systems to understand the actual process that is happening within the emerging technology system [7-8]. The seven functionalities are summarized in the Table 1 . A better fulfilment of system functions means higher chances for development, diffusion and implementation of the emerging technology.

Many studies using system functions analysis to identify factors that accelerates and limits diffusion of an emerging technology. The analysis is done through evaluating indicators for each function. It allows to identify, which functions in technology diffusion is lagging more than the other. The functions analysis can be used in order to develop effective guiding policy with specific targets. For example, Negro (2007) investigated biomass energy in The Netherlands by using TIS approach [9], while Vasseur et al. (2013) using the same approach to compared penetration of photovoltaic (PV) technology in Japan and The Netherlands [10]

Table 1. Functions and Indicators in TIS [10]

\begin{tabular}{|c|c|}
\hline Function & Indicators \\
\hline $\begin{array}{l}\text { Entrepreneurial } \\
\text { Activities }\end{array}$ & 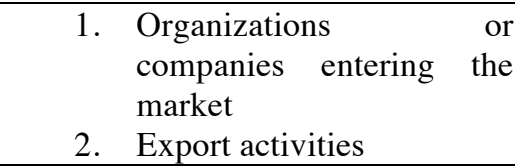 \\
\hline $\begin{array}{l}\text { Knowledge } \\
\text { development }\end{array}$ & $\begin{array}{l}\text { Research and } \\
\text { technological projects } \\
\text { 2. } \begin{array}{l}\text { Demonstration and pilot } \\
\text { projects }\end{array} \\
\text { 3. Learning by doing and } \\
\text { learning by using }\end{array}$ \\
\hline $\begin{array}{l}\text { Knowledge } \\
\text { exchange }\end{array}$ & $\begin{array}{l}\text { National knowledge exchange } \\
\text { between organizations }\end{array}$ \\
\hline $\begin{array}{l}\text { Guidance of } \\
\text { the search }\end{array}$ & $\begin{array}{l}\text { Target set by the government or } \\
\text { industry }\end{array}$ \\
\hline $\begin{array}{l}\text { Market } \\
\text { formation }\end{array}$ & 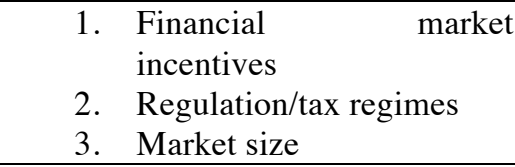 \\
\hline $\begin{array}{l}\text { Resources } \\
\text { Mobilization }\end{array}$ & $\begin{array}{l}\text { 1. Financial resources } \\
\text { 2. Natural resources }\end{array}$ \\
\hline $\begin{array}{l}\text { Creation of } \\
\text { legitimacy }\end{array}$ & $\begin{array}{ll}\text { 1. } & \begin{array}{l}\text { Promotion of the } \\
\text { technology } \\
\text { organizations }\end{array} \\
\text { 2. Lobby activities against or } \\
\text { for the technology }\end{array}$ \\
\hline
\end{tabular}

This study is focusing on the system functions of biodiesel as transport fuel in Indonesia. Export activities in entrepreneurial function is the only international activity that is considered, since it might influence supply of biodiesel on the domestic market. The other international activities, such as international knowledge exchange and foreign direct investment are out of the scope of this study. Data for this study is collected via 
desk research (journals articles, newspapers, reports, and websites).

\section{Result}

The result section subsequently describes the results of the study based on TIS approach. First, TIS structure is described to understand actors, networks and institutional framework of the system. Secondly, the next part of the result section would cover the fulfilment of the system functions analysis. Finally, policy implications for biodiesel penetration is presented in the last part of this section.

\subsection{TIS Structure}

Biodiesel TIS in Indonesia is started with Regulation 1/2006, which enforced its distribution and implementation. To foster the goal, National Biofuels Development Team (Tim Nasional BBN, NBDT) is established through Presidential Decree 20/2006. The first biodiesel mandate was established through MEMR Regulation 32 2008, which enforce biodiesel (B100) implementation by $5 \%$ from total demand of fuel transportation in 2015, 10\% in 2020, and 20\% in 2025. The regulation is revised several times and the latest MEMR Regulation 122015 enforces blending diesel with biodiesel by $20 \%$ (B20) in 2016 and 30\% (B30) in 2025. In addition, GoI sets target for biodiesel production through Regulation 22/2017, which is 11.6 million kilo-litre of biodiesel for transport, industry and electricity sectors.

Howlett et al [11] divided cathegorized actors in Indonesia into eight groups, which is government; international institution; producer or private company; academia; certification agency; state owned enterprise, and non-government organization (NGO). More detail regarding actor and network within TIS is presented in the next section.

\subsection{System Functions Analysis}

\subsubsection{Entrepreneurial Activities}

Entrepreneurial activities turn knowledge of emerging technology into business practice and market-oriented activities. By entrepreneurial activities, the practicality and value proposition of the emerging technology could be proven. However, the emerging technology often follows by unpredictable consequences when it is applied in the society. These consequences create changes to the emerging technology and its institutional context so that it could adapt to the environment and vice versa. This adaptation also required integration from other system function, such as guidance of the search. Thus, entrepreneurial activities are seen as the core activities in TIS framework.
Entrepreneurial activities of biodiesel were mainly driven by Regulation No 1/2006. To help biodiesel industry to adjust, Government of Indonesia (GoI) built the first biodiesel plant with capacity 8,000 tonnes per day in 2005 [12]. Then, many biodiesel companies were established from 2005 until 2008. During 2011, many biodiesel companies were phased out due to high price of CPO and biodiesel competition with fossil-based diesel; the number were decreased from 16 to only 5 [13]. Nevertheless, biorefinery industries were strengthen back in 2009, and further in 2016, when the blending mandate for biodiesel were increased from $15 \%$ to $20 \%$. By 2016 , total production capacity of all the biorefinery plants has reached 10,898 million liter of biodiesel. However, the total production only accounts for $33.5 \%$ of the total capacity.

By 2014, realization of biodiesel blending fuel only reached $73 \%$ from the 1,5 million kilolitres target. Penalties for non-compliance institution is ranging from official warning letter until revocation of business permit. International Council on Clean Transportation (ICCT) reported that none of penalties was given to noncompliance company. Thus, this regulation is still nonbinding for the actors involved within the system [14]. Export demand for biodiesel in 2015 decreased to $75 \%$, from 1,350 million litres to 343 litres, due to low price of fossil fuel and anti-dumping policy by European Union (EU). Export of biodiesel was slightly increased to 478 million litres by 2016. Indonesian biodiesel export in 2017 and 2018 is predicted to be stable, especially after deferment of EU anti-dumping policy [15].

Even though entrepreneurial activities are the core of TIS, it still highly depends on constitutional framework and incentives from the government. The government should keep the incentives high enough, despite the fluctuation of CPO and diesel prices, so that the entrepreneurial activities keep running.

\subsubsection{Knowledge development}

Knowledge development involves learning activities, not limited to the technology, but also the actors, its network, and the market. Main learning activities could be divided into two, i.e. learning by searching and learning by doing. Learning by searching is mostly done by academia and research institution, while learning by doing is conducted by practitioners like entrepreneurs. Knowledge development creates many options for development of emerging technology, which caused uncertainty. However, other system functions, such as guidance of the search and entrepreneurial activities, contribute to the knowledge alignment to fit the environment.

Several universities in Indonesia are involved in knowledge development of biodiesel through conducting several researches. For instance, research about second generation of biodiesel, diversification of feedstock, and laboratories test for biodiesel [11-12]. Universities, such as Universitas Gadjah Mada (UGM) and Institut Teknologi Bandung (ITB), also collaborated with 
automotive industry to use biodiesel in passenger cars [13].

All indicators of knowledge development activities are done by government institution. Research, technological and pilot project on biodiesel are mostly conducted by Agency for the Assessment and Application of Technology (Badan Pengkajian dan Penerapan Teknologi, AAAT) and Indonesian Institute of Science (Lembaga Ilmu Pengetahuan Indonesia, IIoS). While demonstration, learning by doing and learning by using are mostly done by cooperation between Ministry of Energy and Mineral Resources (MEMR); Research and Development Centre for Oil and Gas Technology (Lemigas, RDCOGT); and Ministry of Research, Technology, and Higher Education (MRTEH).

GoI also cooperated with private companies, especially for test drive of vehicle which using biodiesel. For example, performance assessment for vehicle which using biodiesel were done with collaboration with The Association of Indonesia Automotive Industries (Gabungan Industri Kendaraan Bermotor Indonesia, TAIA). The result of demonstration activities is used to improve quality of biodiesel and performance of the vehicle.

Knowledge development functions also aims to create various options for the emerging technology and its applications. For biodiesel in Indonesia, MEMR, IIoS, AAAT and some universities also try to produce biodiesel from raw material other than palm oil, such as microalgae, Schleichera oleosa, Ricinus communis, and Reutealis trisperma [18-21]. Researches for diversity of raw material is limited and still on its early stage. The only pilot project that developed is biodiesel from Ricinus communis, while other material for biodiesel is still in lab-scale research.

Currently, knowledge development of biodiesel in Indonesia focuses on compatibility test and performance assessment of automotive vehicle which using biodiesel. While diversification of raw material beside palm oil is still on its early stage. Collaboration between government institutions, academia, and private companies in these activities have been run. This show that knowledge development function for biodiesel is already fulfilled.

\subsubsection{Knowledge exchange}

Characteristics of TIS organisational structure is the network, in which all actors can interact and have knowledge exchange. Knowledge exchange is expected to engage many actors with different background, such as government, private companies, and researcher. Through frequent knowledge exchange, mutual understanding of the emerging technology could be developed. Furthermore, policy maker can plan the future regulations according to the latest technological insight.

First seminar on bioenergy in general is held on 2008 with the main agenda to discuss the blending mandate [22]. The speakers were RDCOGT, Pertamina EP, Association of Indonesia Biofuel Producers (Asosiasi
Produsen Biofuel Indonesia, AIBP), Indonesia Chambers of Commerce and the committee from EnergyIndependent Village. The second bioenergy seminar was held in 2011, which connected more actors than the previous one [23]. After that in 2015 the biodiesel seminar is more focused on the technical assessment and implementation planning for B20 fuel $[16,17]$.

Even though seminar and exhibition between policy makers and researchers have been done, knowledge exchange between government and society at large, especially consumers, seems to be lacking [24]. Therefore, seminars and knowledge exchange activities to vehicle users and community at large regarding benefit and characteristics of biodiesel should be conducted at a bigger scale.

\subsubsection{Guidance of the search}

Guidance of the search refers to any activities that align the development of emerging technology from all actors, for example, establishment of policy directives, expectations, and promises. Without clear guidance of search, the development of emerging technology will lose focus and other functions, such as knowledge development; knowledge diffusion, and entrepreneurial activities.

The first enforcement for implementation of biodiesel was established through Government Regulation No 1 2006. Then this regulation was followed by other supporting policies, such as Presidential Decree 20/2006 about establishment of biodiesel supervision and Energy Law 2007.

The principal guidance of the search for biodiesel TIS is MEMR Regulation 12/2015, which enforced B20 and $\mathrm{B} 30$ program. The target is to produce 11.6 million kilo-litre of biodiesel for transport, industry and electricity generation in 2025. Currently, GoI focus to produce biodiesel from palm oil, although there are also potential to produce it from Jatropha, sugarcane, and cassava. Palm oil was chosen due to security of supply [14].

However, Ministry of Industry published Regulation $33 / 2013$, which allows the distribution of low cost green car (LCGC) in Indonesia. Enforcement of this regulation created competition between biodiesel and fossil fuel, especially for passenger cars. Additionally, guidance for quality standard of B20 fuel is still missing in the regulation $[9,16,17]$.

\subsubsection{Market formation}

Market formation is required to support the emerging technology compete with the incumbent technology. Activities in market formation can help creating demand for the emerging technology. Market formation is important, especially for sustainable energy technology, because fossil-based energy does not internalize external cost, like its environment effect. Some examples of market formation are marketing campaign with temporary discount, subsidy, institutional framework to account for external cost, etc. 
Since 2015, the current blending mandate is funded from tax levy on exported crude palm oil (CPO), which is enforced through Regulation 24/2015 and 61/2015. CPO exporters requires pay for the levy if the price of CPO is under USD 750. If the price of CPO goes beyond USD 750, the exporters are expelled to pay the levy, but instead they required to pay for regular export tax. This CPO export fund is utilized to offset the price gap between biodiesel and fossil-based diesel and support research and development of biodiesel.

In May 2017, MEMR reduced amount of paid per unit for biodiesel blenders. The regulation imposed that the amount paid to the blenders were summation of average CPO Price and USD 125/MT of biodiesel, which became USD 100/MT in the current regulation. Reduction of biodiesel revenue might weaken the domestic market and made international market more attractive.

Palm oil tax levy is the only market formation regulation that enforced in Indonesia. No other incentive and tax beside palm oil export levy have been issued to the current date.

\subsubsection{Resources Mobilization}

Resources mobilization refers to allocation of financial and natural resources to support the emerging technology. Typical activities in resources mobilization are investments and subsidies.

By 2016, total revenues from palm oil export tax reached 9.5 trillion Rupiah (USD 698 million) which is claimed to be enough to fund all blending mandate program, including to offset the price gap between diesel and biodiesel, and to fund research and development of biodiesel. Global Agricultural Information Network (GAIN) reported that the actual blending levels of biodiesel in the market were correlated with the amount of funding from palm oil levy. Thus, fluctuation of palm oil export will influence amount of biodiesel blending.

Biodiesel mandate increased demand of palm oil, which leads to more area required for palm oil plantation. However, the biofuel production currently causes $6.5 \%$ of annual deforestation in Indonesia [26]. With biodiesel mandate, Indonesia requires 5.15-6 million ha additional land for palm oil plantations [20, 21]. The required area for palm oil expansion for biodiesel is $11-17$ Mha without jeopardizing policy on agriculture, forestry, and climate mitigation resources [28], while the available area for biodiesel is 20.9 Mha [29]. The required area for biodiesel could be reduced if there is an increased palm oil yield per area of plantation (tonne of palm oil per plantation area). Palm oil yields could be increased by $20 \%$ with intensification of plantation, such as crop recovery, canopy management and soil, moisture, and nutrient management [30].

Biodiesel resources mobilization consist of the allocation of financial and natural resources. Palm oil tax levy is the main funding source for blending mandate program. Although the available land in Indonesia is sufficient to meet biodiesel target, sustainability indicators for biodiesel production is still missing.

\subsubsection{Creation of legitimacy}

Emerging of new technology into the system is followed with resistance by some actor in the incumbent energy system [31]. The actors which against the change usually do political lobbies or advice activities to hinder penetration of the emerging technology. In order to diffuse the technology, other supporting actor should hold counteract lobbies and promotion activities. These creations of legitimacy will push the decision maker to fasten or limit the technology.

Despite the solid financial funding, the gap between biodiesel and fossil-based diesel price has greatly increased, as shown in Figure 4. Thus, biodiesel blenders asked the Government to revise the subsidy in response to the change.

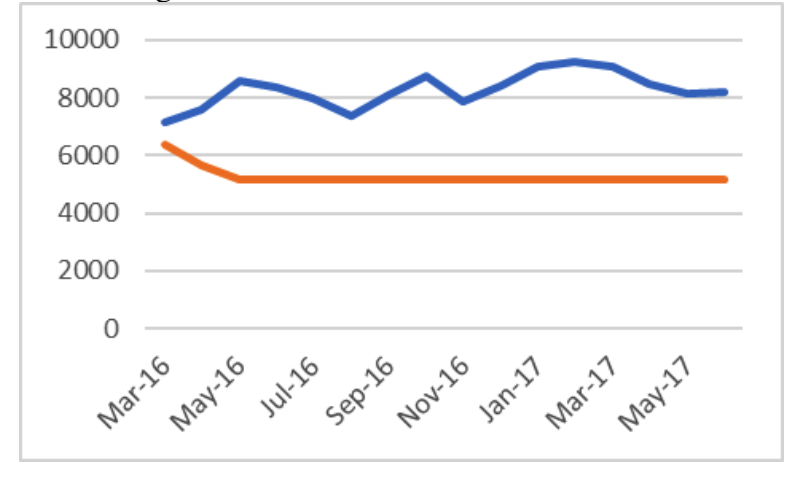

Figure 3. Biodiesel Market Price Compared to Fossil-based Diesel (Unit: IDR/liter) [4]

Enforcement of CPO tax levy reduced income of palm oil farmers. Indonesian Palm Oil Association (Gabungan Pengusaha Kelapa Sawit Indonesia, IPOA) continually asks the government to reduce the palm oil tax levy and replace it with other tax regime, such as carbon credit for fossil fuel user. In addition, palm oil farmers, under Association of Plasma Palm Oil Farmers (Asosiasi Petani Plasma Kelapa Sawit, APPOF), sent objection and judicial review regarding CPO levy fund to Indonesia Supreme Court [28-29]. APPOF demands the abolishment of the tax levy due to allegation that there is a corruption practice in the levy fund [34]. These cases have been running since 2016 and are still under investigation. Despite all the projections, GoI is still determined to meet the biodiesel mandate by 2025 .

\section{Discussion}

Institutional framework for implementation of biodiesel seems to be clear, where the specific target of blending mandate exists. However, several upcoming policies by the GoI leads to uncertainty towards diffusion of biodiesel technology. For example, reduction of unit paid for biodiesel blenders and support of LCGC. This uncertainty has also created more risk for the entrepreneurs.

Taking Sweden as a benchmark, uncertainty in implementation of biofuels could be removed by having a clear guidance of the search on its early stages, which is called the Three-Party Agreement 1991 [31]. This 
agreement is followed by multi-sectoral strategy to support biofuel deployment.

Besides supporting the emerging technology, government also requires to put tax for the incumbent energy source to reduce competition. This tax could increase biodiesel demand and reduce the risk of biodiesel producers. Tax on fossil fuel would also help the government to have financial sources for blending mandate program beside palm oil tax levy. Thus, putting tax on fossil fuel would influence system functions in Market Formation; Resources Mobilization and Entrepreneurial Activity.

Other challenge that hinder diffusion of technology is the lack of awareness by the end-users. To tackle this challenge promotion and broader knowledge exchange about biodiesel product should be initiated by the government. Knowledge Exchange regarding negative consequences of fossil-based fuel would also increase people awareness. With higher awareness from the society, the urge to shift to renewable energy, such as biodiesel, is expected to increase [31]. This activity would advance system functions in Knowledge Development and Exchange, Creation of Legitimation, and Market Formation.

Enforcement of policy and regulation should be accompanied with commitment and willingness from all the actors. Government should also be consistent, especially in giving penalties to the non-compliance actors. Funding management, tenders, projects, and other activities within the system should be transparent to gather trust from the society and in order to reduce activities that against the diffusion of the technology.

\section{Conclusion and Policy Implications}

Biodiesel blending mandate has been established in Indonesia since 2006. But after 11 years of implementation, penetration of biodiesel in the market is still under the target. TIS approach allows us to map all the lagging aspects during the diffusion of biodiesel technology through system function analysis. Some challenges that should be addressed are lax regulation; price fluctuation due to $\mathrm{CPO}$ and fossil fuel price; lack of awareness from the society; inconsistency of policy lead to competition with fossil fuel; vulnerable financial funding from palm oil tax levy; lack of sustainability indicators for palm oil; and policy objection regarding palm oil tax levy.

An agreement between all the actors is required to clarify the situation about the future of the technology. The agreement should be followed by the strategy or guiding policy to support the technology. In biodiesel TIS, GoI has already put incentives for biodiesel blenders to offset the price between biodiesel and fossilbased diesel. Nevertheless, negative consequences of fossil fuel in Indonesia has not been internalized in the price; instead, the fossil fuel is still subsidized. Additionally, tax on fossil fuel could be the financial source for blending mandate program other than the palm oil tax levy. A broader knowledge exchange and promotion of biodiesel should also reach everyone in the society, and not be limited to researchers and private company owners. If the society has higher awareness about biodiesel, it is expected that the demand will increase.

With diffusion of biodiesel, GoI would be able to reduce the dependence on fossil fuel, increase the share of renewable energy and reduce the greenhouse gas emission in the country. However, sustainability indicators for palm oil production should be introduced to minimize environment effect of palm oil plantation.

\section{References}

1. British Petroleum, "BP Statistical Review of World Energy," (2017).

2. International Energy Agency, "IEA Sankey Diagram," 2014. [Online]. Available: https://www.iea.org/Sankey/\#?c=Indonesia\&s=Fin al consumption. [Accessed: 24-Aug-2017].

3. Statistics of Indonesia, "Land Transportation Statistics 2015," Jakarta, 8302004, (2016).

4. T. Wright, A. Rahmanulloh, and A. Abdi, “Indonesia Biofuels Annual Report 2017," Global Agriculture Information Network (GAIN), Jakarta, ID1714, (2017).

5. A. Daryanto, "Urgensi pengembangan sumber energi terbarukan," Bogor Agriculture Institute (IPB), Bogor, (2010).

6. B. A. Purwanto, E. Hambali, Y. Arkeman, and H. Wijaya, "Formulating a Long Term Strategy for Sustainable Palm Oil Biodiesel Development in Indonesia," J. Sustain. Dev., vol. 9, no. 4, pp. 124132, (2016).

7. A. Bergek, S. Jacobsson, B. Carlsson, S. Lindmark, and A. Rickne, "Analyzing the functional dynamics of technological innovation systems: A scheme of analysis," Res. Policy, vol. 37, no. 3, pp. 407-429, (2008).

8. M. P. Hekkert and S. O. Negro, "Functions of innovation systems as a framework to understand sustainable technological change: Empirical evidence for earlier claims," Technol. Forecast. Soc. Change, vol. 76, no. 4, pp. 584-594, (2009).

9. S. O. Negro, M. P. Hekkert, and R. E. Smits, "Explaining the failure of the Dutch innovation system for biomass digestion-A functional analysis," Energy Policy, vol. 35, no. 2, pp. 925938, (2007).

10. V. Vasseur, L. M. Kamp, and S. O. Negro, “A comparative analysis of Photovoltaic Technological Innovation Systems including international dimensions: the cases of Japan and The Netherlands," J. Clean. Prod., vol. 48, pp. 200-210, (2013).

11. M. Howlett, I. Mukherjee, and J. Koppenjan, "Policy learning and policy networks in theory and practice: the role of policy brokers in the Indonesian biodiesel policy network," Policy Soc., vol. 36, no. 2, pp. 233-250, (2017). 
12. Merdeka, "Menristek Resmikan Pabrik Biodisel Pertama di Indonesia," merdeka.com, Jan-2005. [Online]. Available: https://www.merdeka.com/uang/menristekresmikan-pabrik-biodisel-pertama-di-indonesiax0a1bv6.html. [Accessed: 02-Sep-2017].

13. N. Panjaitan, "Development of Biofuel Technology in Indonesia," TU Delft, Delft, 2013.

14. A. Kharina, C. Malins, and S. Searle, "BIOFUELS POLICY IN INDONESIA: OVERVIEW AND STATUS REPORT," (2016).

15. Reuters, "EU postpones decision on biodiesel antidumping duties," Jul-2017. [Online]. Available: https://www.reuters.com/article/us-eu-biodieselidUSKBN1AC2A3. [Accessed: 28-Aug-2017].

16. SB, "Kemenristekdikti Danai 7 Inovasi Perguruan Tinggi," Technology Indonesia, 2016. [Online]. Available: http://www .technologyindonesia.com/index.php/component/content/articl e/129-umum/974-kemenristekdikti-danai-7inovasi-perguruan-tinggi. [Accessed: 03-Sep2017].

17. A. Susanti, "Enam Kampus Siap Kembangkan Inovasi ke Industri," Okezone, Mar-2016. [Online]. Available: https://news.okezone.com/read/2016/03/07/65/132 9569/enam-kampus-siap-kembangkan-inovasi-keindustri. [Accessed: 03-Sep-2017].

18. Y. K. Irawan, "Kalbar Kembangkan Kemiri Sunan untuk Bahan Baku Biodiesel," KOMPAS.com, Jun-2016. [Online]. Available: http://bisniskeuangan.kompas.com/read/2016/06/2 9/160000626/kalbar.kembangkan.kemiri.sunan.unt uk.bahan.baku.biodiesel. [Accessed: 10-Sep2017].

19. Ministry of Energy and Mineral Resource (MEMR), "Pengembangan Kemiri Sunan di Daerah Pertambangan," Pengembangan Kemiri Sunan di Daerah Pertambangan, Dec-2013. [Online].

Available: http://litbang.esdm.go.id/berita/penelitian-danpengembangan-mikroalga-sebagai-bahan-bakubiodiesel. [Accessed: 10-Sep-2017].

20. Indonesian Institute of Science, "LIPI dan IPB Lirik Biji Kesambi NTT," Mar-2011. [Online]. Available: http://lipi.go.id/berita/single/LIPI-danIPB-Lirik-Biji-Kesambi-NTT/6469. [Accessed: 10-Sep-2017].

21. Indonesian Institute of Science, "Biodiesel Alga Hijau Biru Masuk PPRI LIPI," Oct-2007. [Online]. Available: http://lipi.go.id/berita/single/Biodiesel-AlgaHijau-Biru-Masuk-PPRI-LIPI/1476. [Accessed: 10-Sep-2017].

22. H. S. Dillon, T. Laan, H. S. Dillon, International Institute for Sustainable Development, Global Subsidies Initiative, and International Institute for Sustainable Development, Biofuels, at what cost? : government support for ethanol and biodiesel in Indonesia. Winnipeg, Man.: International Institute for Sustainable Development, (2008).
23. Ministry of Energy and Mineral Resource (MEMR), “Indo-Bioenergy 2011,” Jun-2011. [Online]. Available: http://www3 .esdm.go.id/siaran-pers/55-siaranpers/4528-indo-bioenergy-2011 html. [Accessed: 03-Sep-2017].

24. Bioenergy Division, "Kajian Teknis dan Uji Pemanfaatan Biodiesel 20\% Pada Kendaraan Bermotor dan Alat Besar," presented at the Seminar on Technical Assessment and B20 Implementation, Jakarta, (2015).

25. B. Restituta, I. Paryanto, and R. Riza, "Spesifikasi Mutu B-20 di Indonesia dan Perbandingannya dengan Spesifikasi Biodiesel, Minyak Solar dan Standard International," presented at the Seminar on Technical Assessment and B20 Implementation, Jakarta, (2015).

26. K. Obidzinski, R. Andriani, H. Komarudin, and A. Andrianto, "Environmental and Social Impacts of Oil Palm Plantations and their Implications for Biofuel Production in Indonesia," Ecol. Soc., vol. 17, no. 1, (2012).

27. A. Rahmadi, L. Aye, and G. Moore, "The feasibility and implications for conventional liquid fossil fuel of the Indonesian biofuel target in 2025," Energy Policy, vol. 61, pp. 12-21, (2013).

28. F. Harahap, C. Palmen, S. Silveira, and D. Khatiwada, "Conditions for a sustainable development of palm-oil-based biodiesel in Indonesia," (2016).

29. F. Harahap, S. Silveira, and D. Khatiwada, "Land allocation to meet sectoral goals in Indonesia-An analysis of policy coherence," Land Use Policy, vol. 61, pp. 451-465, (2017).

30. C. R. Donough, C. Witt, T. H. Fairhurst, and others, "Yield intensification in oil palm plantations through best management practice," Better Crops, vol. 93, no. 1, pp. 12-14, (2009).

31. R. A. A. Suurs, "Motors of Sustainable Innovation," Utrecht University, Utrecht, (2009).

32. M. S. Widodo and B. Febriana, "Murah Harga Pungutan Digugat," GATRA, Jakarta, (2016).

33. D. Ningsih, "Petani Plasma Protes Pungutan Sawit," Berita Satu, Jakarta, (2016).

34. Global News, "KAKI Desak KPK Audit Investigasi Penyelewengan Dana Pungutan CPO," Global News, (2017). . 